\title{
SISTEM PENGOLAHAN CITRA DIGITAL UNTUK MENENTUKAN BOBOT SAPI MENGGUNAKAN METODE TITIK BERAT
}

\author{
Ahmad Mustafid', Shofwatul 'Uyun' \\ Jurusan Teknik Informatika, Fakultas Sains dan Teknologi, UIN Sunan Kalijaga \\ Jl. Marsda Adisucipto Yogyakarta 55281 \\ email: ${ }^{1}$ ahmad.mstfd@gmail.com; ${ }^{2}$ shofwatul.uyun@uin-suka.ac.id
}

(Naskah masuk: 05 Juni 2018, diterima untuk diterbitkan: 11 November 2018)

\begin{abstract}
Abstrak
Harga sapi umumnya ditentukan melalui tawar menawar antara penjual dan pembeli serta interaksi antara permintaan dan penawaran bukan didasarkan pada bobot sapi yang akan dijual. Sebagian besar perhitungan dilakukan secara kasar maupun kira-kira. Ukuran lingkar dada dan panjang badan sapi diperlukan untuk menghitung bobot sapi dengan menggunakan rumus Schrool maupun rumus Modifikasi/Lambourne. Kenyataan di lapangan menunjukkan bahwa untuk mendapatkan nilai lingkar dada dan panjang badan perlu dilakukan pengukuran secara manual, serta hal tersebut tidak mudah untuk dilakukan dikarenakan sapi yang sulit dikondisikan. Oleh sebab itu, diperlukan alat yang bisa mengukur secara mudah. Penelitian kali ini merupakan tahap kedua untuk menghitung dan menentukan bobot dari sapi dari proses akuisisi citra. Oleh karena itu, pada tahapan kedua ini hanya difokuskan kepada pemilihan rumus penentuan bobot sapi dan usulan algoritma untuk menentukan bobot dari gambar hasil akuisisi citra. Hasil analisis bobot sapi menggunakan rumus Schoorl dan rumus Modifikasi/Lambourne memiliki nilai deviasi bobot badan sebesar 16,87\% dan 10,58\%. Hasil analisis dan perhitungan citra tidak berbeda secara signifikan dengan nilai MAE (Mean Absolute Error) sebesar 8,15\% untuk panjang badan dan 4,10\% untuk lingkar dada. Aplikasi pengolahan citra digital yang telah dibangun mampu mengetahu berat badan/bobot sapi dengan MAE (Mean Absolute Error) sebesar 8,97\% terhadap rumus Modifikasi/Lambourne.
\end{abstract}

Kata kunci: Harga Sapi, Bobot Sapi, Lingkar Dada, Panjang Badan, Akuisisi Citra, Algoritma Pengolahan Citra Digital, Rumus Schrool, Rumus Modifikasi/Lambourne.

\section{DIGITAL IMAGE PROCESSING SYSTEM FOR DETERMINING THE WEIGHT COW USING CENTER OF GRAVITY METHOD}

\begin{abstract}
The price determination of cows is generally agreed through bargaining and interacting with demand and supply to establish the general level of the price but it is not based on the weight of the cow itself. The tool that the most commonly used is by rough calculation or approximation. There were formulas to measure the weight, but it required chest circumference and the length of the body information. The values ware obtained manually using the measuring tool, but the reality is inconvenient to do, because of the difficulty conditioning the cows. Therefore, it required a tool that can calculate easily. This article represented the second stages of the research to determine the weight of cows from the image acquisition. Consequently, at this second stage has been focused on the selection of the cow weighting formula and the proposed algorithm to determine the weight from the result of images that had been processed in the early stages. The result of cow weighting analysis using Schoorl formula and Modification/Lambourne formula had the value of body weight deviation of $16.87 \%$ and 10.58 . The results of image calculation did not differ significantly with MAE (Mean Absolute Error) equal to 8,15\% and 4,10\% for body length and chest circumference, respectively. Digital image processing application that has been built was able to know the weight of cow with MAE (Mean Absolute Error) equal to 8,97\% towards Modification/Lambourne formula.
\end{abstract}

Keywords: Cow Prices, Cow Weight, Chest Circumference, Body Length, Image Acquisition, Digital Image Processing Algorithm, Schoorl Formula, Modification/Lambourne Formula. 


\section{PENDAHULUAN}

Populasi sapi di Indonesia sebesar 15,4 juta ekor, termasuk sapi potong dan sapi perah. Pertumbuhan populasi sapi dari tahun 2003 sampai tahun 2011 mencapai 5,33\% per tahun atau dengan nilai rata-rata pertambahan 655,5 ribu ekor setiap tahunnya (Kementan-BPS, 2011). Ternak Sapi mempunyai nilai ekonomis yang tinggi di masyarakat. Harga sapi umumnya ditentukan melalui interaksi antara penawaran dan permintaan barang serta tawar menawar antara pembeli dan penjual bukan didasarkan pada bobot sapi yang dijual.

Bobot sapi dapat dihitung dengan rumus Schoorl dan rumus Modifikasi/Lambourne yang membutuhkan variabel panjang badan dan lingkar dada untuk perhitungannya. Untuk mendapatkan bobot badan diperlukan nilai lingkar dada dan panjang badan (Pradana, Hidayat, \& Darana, 2016) yang diukur secara manual (Paputungan et al., 2013). Namun, kenyataan di lapangan menunjukkan bahwa untuk mendapatkan nilai lingkar dada dan panjang badan perlu dilakukan pengukuran secara manual, serta hal tersebut tidak mudah untuk dilakukan dikarenakan sapi yang sulit dikondisikan. Di lapangan sendiri, belum adanya alat untuk menghitung lingkar dada, panjang badan dan bobot sapi secara praktis dan akurat. Diawali dari permasalahan ini, memunculkan ide untuk membuat alat yang bisa mengukur secara akurat dan mudah.

Pengolahan Citra Digital merupakan pemrosesan gambar atau citra dengan menggunakan perangkat komputer untuk membuat citra yang memiliki kualitas lebih baik (Munir, 2004). Citra digital adalah suatu fungsi dua dimensi $\mathrm{f}(\mathrm{x}, \mathrm{y})$, dengan f merupakan fungsi amplitudo pada posisi $(\mathrm{x}, \mathrm{y})$ yang biasa disebut dengan intensitas, dengan $\mathrm{x}$ maupun $\mathrm{y}$ adalah posisi koordinat citra. (Purnomo \& Muntasa, 2010)

Pada penelitian ini akan dibahas langkah kedua dalam penentuan bobot sapi yaitu dengan penentuan rumus, konversi satuan serta usulan beberapa algoritma yang digunakan untuk menentukan bobot sapi. Hasil dari masing-masing algoritma akan dievaluasi dan dihitung tingkat akurasi dari masingmasing algoritma. Terdapat beberapa penelitian yang serupa yang menggunakan pengolahan citra dengan objek sapi (Lasfeto, Susanto, \& Agus, 2008); (Cholissodin, Soebroto, \& Hidayat, 2015).

Pada penelitian sebelumnya (Mustafid \& 'Uyun, 2017), telah dibahas tentang segmentasi berbasis deteksi tepi terhadap citra sapi dengan menggunakan kombinasi antara algoritma Canny dengan operator Median Blur serta Sharp, kemudian dilakukan ujicoba beberapa langkah dan cara untuk menghasilkan citra dengan deteksi tepi terbaik dengan cara menghitung MSE (Mean Square Error) dan PSNR (Peak Signal to Noise Ratio) pada masingmasing percobaan deteksi tepi. Hasil deteksi tepi terbaik dari penelitian yang pertama telah menghasilkan citra yang merupakan tahap preprocessing. Hasil dari penelitian tadi berupa citra hasil preprocessing yang akan digunakan pada penelitian kali ini.

\section{METODE PENELITIAN}

\subsection{Titik Berat}

Titik berat adalah titik dimana berat keseluruhan benda terpusat pada titik tersebut. Untuk benda dengan bentuk homogen yang simetris titik beratnya dapat dihitung menggunkana persamaan pada Tabel 1.

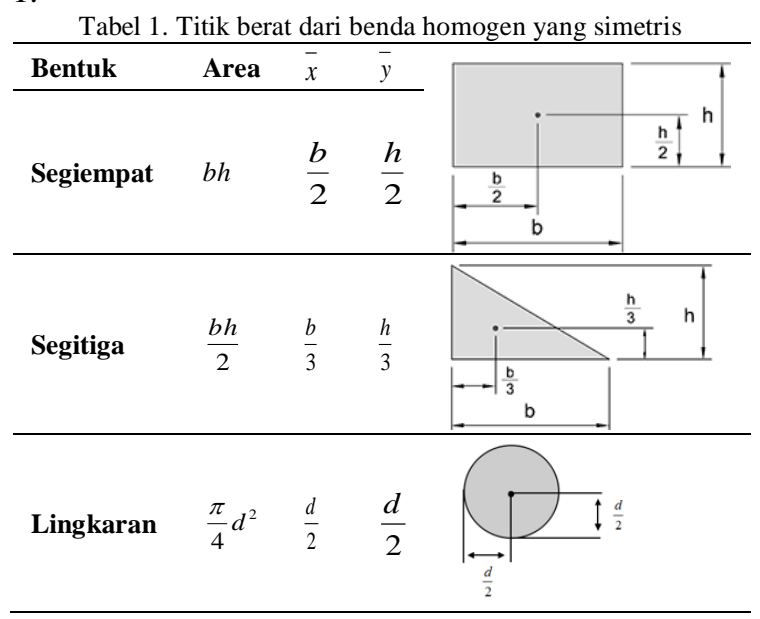

Untuk benda homogen tetapi tidak simetris kita dapat menggunakan rumus (1) dan (2), dengan $\bar{x}$ adalah koordinat titik berat dari sumbu $\mathrm{x}$, dan $\bar{y}$ adalah koordinat titik berat dari sumbu y (Rajput, 1988)

$$
\begin{aligned}
& \bar{x}=\frac{a_{1} x_{1}+a_{2} x_{2}+\ldots . .+a_{n} x_{n}}{a_{1}+a_{2}+\ldots . .+a_{n}} \\
& \bar{x}=\frac{\sum a x}{\sum a} \\
& \bar{y}=\frac{a_{1} y_{1}+a_{2} y_{2}+\ldots . .+a_{n} y_{n}}{a_{1}+a_{2}+\ldots . .+a_{n}} \\
& \bar{y}=\frac{\sum a y}{\sum a}
\end{aligned}
$$

\subsection{Rumus Perhitungan}

Sapi Merupakan Hewan Ternak yang digolongkan sebagai hewan yang dapat memenuhi konsumsi daging masyarakat. Daging yang dihasilkan sapi merupakan bahan makanan yang dapat dikonsumsi oleh manusia.

Hubungan Antara ukuran tubuh ternak sapi dengan badan terdapat persamaan yang linear (Ensminger \& Olentine, 1980). Cara penentuan bobot badan sapi potong ditunjukkan seperti pada Gambar 1 . 


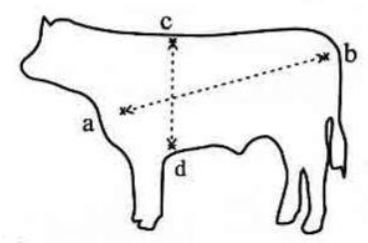

Gambar 1. Mengukur panjang badan dan lebar dada (Determination of body lenght and chest diameter)

\section{Keterangan Gambar :}

a - b : Panjang Badan (Body Length)

c - d : Lingkar Dada (Chest Diameter)

Panjang Badan (PB), titik (a) ke titik (b), adalah panjang yang dihitung dari titik bahu ke tulang duduk (pin bone).

Lingkar Dada (LD), melingkar dari titik (c) ke titik (d) dan kembali ke titik (c), adalah panjang yang diukur melingkar pada posisi di bagian belakang kaki depan dan belakang tonjolan pundak sapi di bagian atas. (Abidin, 2002).

$$
\begin{array}{r}
\text { Rumus Schrool: } \\
\text { BeratBadan }=\frac{(L D+22)^{2}}{100}
\end{array}
$$

$$
\begin{aligned}
& \text { Rumus Modifikasi/Lambourne: } \\
& \text { BeratBadan }=\frac{P B+L D^{2}}{10840} \\
& \mathrm{LD}=\text { Lingkar Dada (dalam } \mathrm{cm} \text { ) } \\
& \mathrm{PB}=\text { Panjang Badan (dalam } \mathrm{cm})
\end{aligned}
$$

\subsection{Alur Penelitian}

Langkah-langkah penelitian yang dilakukan yaitu pertama citra sapi yang sudah diproses akan menjadi inputan pada sistem yang akan dikembangkan. Pada tahap pengembangan sistem dibutuhkan dua tahapan yaitu tahap penentuan rumus berat badan badan yang nanti akan membandingan dua buah rumus untuk penentuan berat badan dan tahap konversi satuan akan menghasilkan hasil konversi satuan yang akan digunakan pada tahap

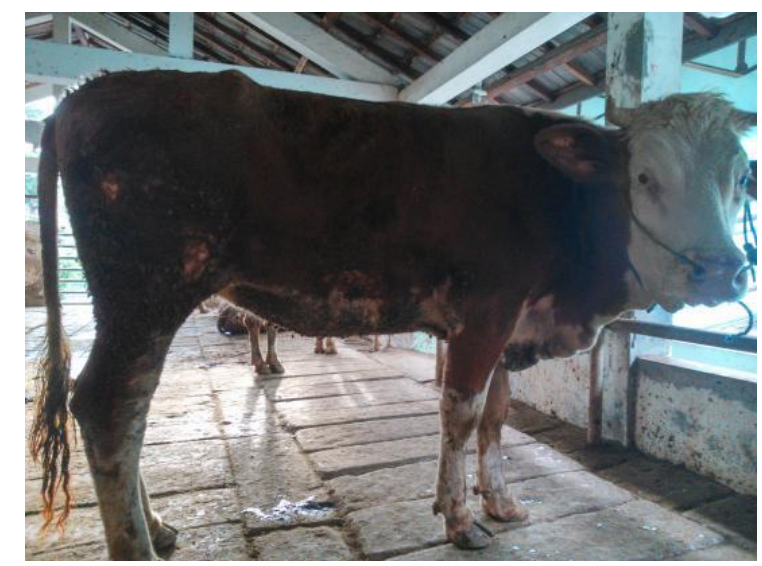

Gambar 4. Citra Awal pengembangan sistem. Metode Penelitian ditunjukkan oleh Gambar 2.

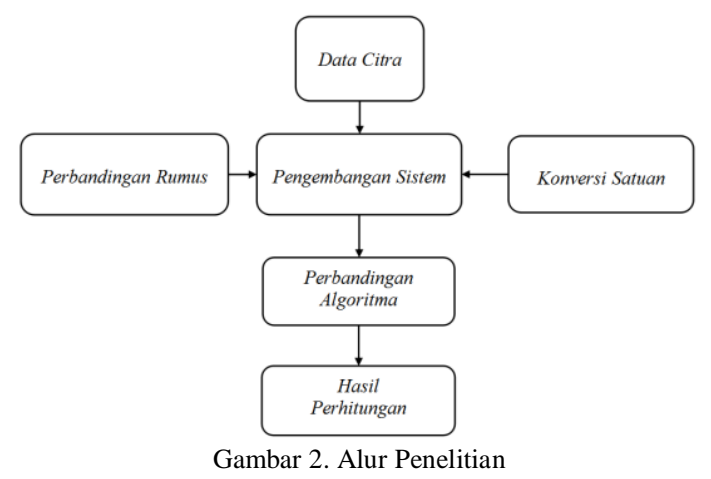

Proses akuisisi citra untuk mendapatkan data awal dilakukan dengan cara memotret objek sapi dengan jarak $150 \mathrm{~cm}$ dari objek ke kamera serta dengan jarak tinggi $75 \mathrm{~cm}$ dari tanah ke kamera. Kamera yang digunakan adalah kamera yang memiliki resolusi 8 megapiksel. Proses akuisisi citra dapat dilihat pada Gambar 3.

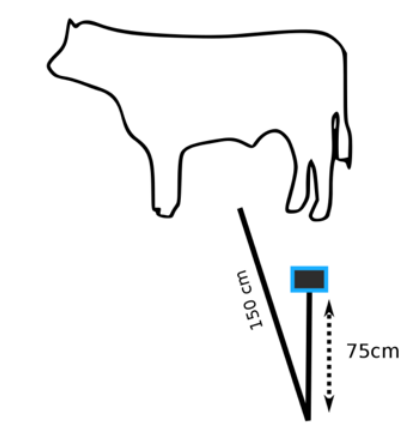

Gambar 3. Proses Akuisisi Citra

Dalam penelitian ini terdapat 10 data citra sapi yang dihasilkan dari penelitian sebelumnya. Data citra merupakan data yang sudah melalui tahap preprocessing.

Citra awal berupa gambar dengan objek sapi seperti pada Gambar 4. dan hasil dari preprocessing yang telah dilakukan menghasilkan citra seperti pada Gambar 5.

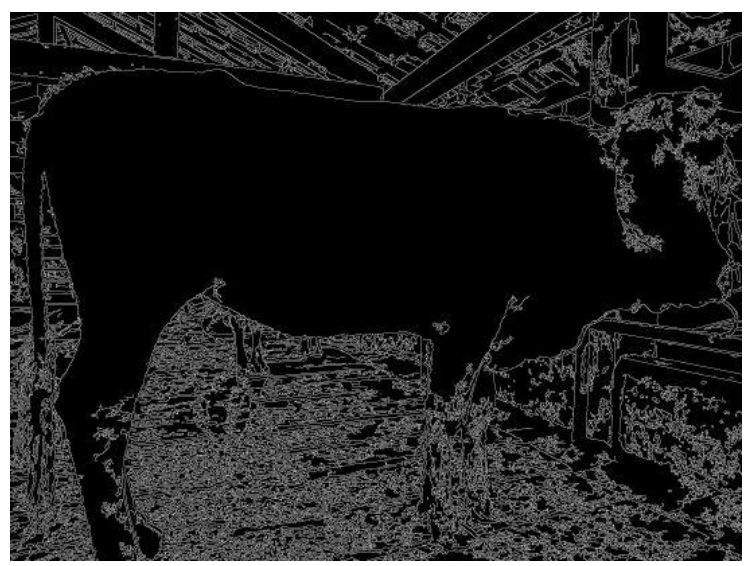

Gambar 5. Citra Hasil Preprocessing 


\section{HASIL DAN PEMBAHASAN}

\subsection{Perbandingan Rumus}

Pada tahap ini akan dibandingkan dua rumus yang digunakan untuk menentukan bobot badan, rumus yang terbaik nantinya akan digunakan pada proses perhitungan penentuan bobot badan berikutnya. Rumus yang dibandingkan adalah rumus
Schrool (3) dan rumus Modifikasi/Lambourne (4). Rumus yang ada akan dibandingkan dengan hasil pengukuran yang telah dilakukan secara langsung terhadap 19 sapi. Tabel 2. menunjukkan perbandingan selisih bobot badan dengan Rumus Schrool dan rumus Modifikasi/Lambourne terhadap bobot badan.

Tabel 2. Tabel Perbandingan Rumus Schoorl dan Rumus Modifikasi/Lambourne

\begin{tabular}{|c|c|c|c|c|c|c|c|c|}
\hline \multirow{2}{*}{ No. } & \multirow{2}{*}{ Kode } & \multirow{2}{*}{$\begin{array}{c}\text { Bobot } \\
\text { Badan } \\
(\mathbf{k g})\end{array}$} & \multirow{2}{*}{$\begin{array}{l}\text { Bobot Badan } \\
\text { Rumus schoorl } \\
(\text { kg) }\end{array}$} & \multicolumn{2}{|c|}{ Penyimpangan } & \multirow{2}{*}{$\begin{array}{c}\text { Bobot Badan } \\
\text { Rumus } \\
\text { modifikasi } \\
(\mathrm{kg})\end{array}$} & \multicolumn{2}{|c|}{ Penyimpangan } \\
\hline & & & & $\begin{array}{c}\text { Selisih } \\
(\mathrm{kg})\end{array}$ & $\%$ & & $\begin{array}{c}\text { Selisih } \\
(\mathrm{kg})\end{array}$ & $\%$ \\
\hline 1 & A & 344 & 408,04 & 64,04 & 18,62 & 406,49 & 62,49 & 18,17 \\
\hline 2 & B & 355 & 392,04 & 37,04 & 10,43 & 342,91 & 12,09 & 3,41 \\
\hline 3 & $\mathrm{C}$ & 345 & 408,04 & 63,04 & 18,27 & 358,67 & 13,67 & 3,96 \\
\hline 4 & D & 168 & 262,44 & 94,44 & 56,21 & 215,17 & 47,17 & 28,08 \\
\hline 5 & $\mathrm{E}$ & 483 & 501,76 & 18,76 & 3,88 & 519,46 & 36,46 & 7,55 \\
\hline 6 & F & 315 & 345,96 & 30,96 & 9,83 & 347,37 & 32,37 & 10,27 \\
\hline 7 & G & 308 & 349,69 & 41,69 & 13,54 & 331,52 & 23,52 & 7,64 \\
\hline 8 & $\mathrm{H}$ & 376 & 342,25 & 33,75 & 8,98 & 343,14 & 32,86 & 8,74 \\
\hline 9 & I & 348 & 361,00 & 13,00 & 3,74 & 322,86 & 25,14 & 7,22 \\
\hline 10 & $\mathrm{~J}$ & 370 & 424,36 & 54,36 & 14,69 & 421,64 & 51,64 & 13,96 \\
\hline 11 & $\mathrm{~K}$ & 203 & 237,16 & 34,16 & 16,83 & 180,03 & 22,97 & 11,32 \\
\hline 12 & $\mathrm{~L}$ & 330 & 320,41 & 9,59 & 2,91 & 329,71 & 0,29 & 0,09 \\
\hline 13 & M & 333 & 357,21 & 24,21 & 7,27 & 424,51 & 91,51 & 27,48 \\
\hline 14 & $\mathrm{~N}$ & 439 & 384,16 & 54,84 & 12,49 & 508,32 & 69,32 & 15,79 \\
\hline 15 & $\mathrm{O}$ & 260 & 324,00 & 64,00 & 24,62 & 251,02 & 8,98 & 3,45 \\
\hline 16 & $\mathrm{P}$ & 149 & 234,09 & 85,09 & 57,11 & 161,48 & 12,48 & 8,37 \\
\hline 17 & $\mathrm{Q}$ & 231 & 282,24 & 51,24 & 22,18 & 220,24 & 10,76 & 4,66 \\
\hline 18 & $\mathrm{R}$ & 203 & 234,09 & 31,09 & 15,32 & 194,72 & 8,28 & 4,08 \\
\hline 19 & S & 432 & 416,16 & 15,84 & 3,67 & 504,19 & 72,19 & 16,71 \\
\hline \multicolumn{2}{|c|}{ Total } & 5992 & 6585 & 821,10 & 320,57 & 6383 & 634,20 & 200,94 \\
\hline \multicolumn{2}{|c|}{ Rata-rata } & 315,4 & 346,6 & 43,22 & 16,87 & 335,97 & 33,38 & 10,58 \\
\hline
\end{tabular}

Penyimpangan rumus Modifikasi/Lambourne $(10,58 \%)$ lebih kecil dibandingkan dengan penyimpangan rumus Schoorl $(16,87 \%)$. sehingga pada tahap selanjutnya untuk menghitung bobot/berat badan sapi, digunakan rumus Modifikasi/Lambourne dalam penentuan bobot badan.

\subsection{Konversi Satuan}

Konversi Satuan merupakan proses kalibrasi untuk mendapatkan skala konversi unit piksel ke unit centimeter yang nantinya akan digunakan untuk menghitung panjang badan dan lingkar dada pada objek sapi. Proses ini menggunakan rumus (5) yang didapatkan dari hasil perhitungan dengan cara menghitung nilai perbandingan antara nilai panjang pada bidang proyeksi pengambilan citra di lapangan atau Panjang nyata objek (Pi) dengan nilai Panjang citra objek di monitor (Pxi). Untuk mendapatkan rumus (5) ini dilakukan percobaan dengan cara mengambil citra objek contoh yang sudah diketahui panjangnya dengan jarak yang sudah ditentukan kemudian membandingkan nilai panjang objek nyata dengan panjang objek di citra, didapatkanlah rumus
(5) dengan nilai $\mathrm{R}$ sebagai nilai skala konversi unit piksel ke unit centimeter pada penelitian ini.

$$
R=\frac{\sum_{i=1}^{n} \frac{P i}{P x i}}{n} \mathrm{~cm} / p x
$$

Hasil dari perhitungan didapatkan nilai $\mathrm{R}$ yaitu 0,06 $\mathrm{cm} / \mathrm{px}$. Untuk gambar yang diambil dari kamera dengan resolusi 8 Megapiksel (3264x2448) dengan jarak pengambilan gambar antara objek dengan kamera $150 \mathrm{~cm}$. Dengan menggunakan nilai skala konversi R, nilai Panjang nyata suatu objek $(\mathrm{O})$ dalam $\mathrm{cm}$ dapat dihitung dari Panjang suatu objek (Ox) dalam satuan piksel dari sebuah citra. Kita dapat menghitung menggunakan rumus (6)

$$
O=O x * R \text {. }
$$

\subsection{Pengembangan Sistem}

Pada tahap pengembangan sistem, sistem dibuat menggunakan bahasa java pada sistem operasi Android. Perangkat yang digunakan adalah perangkat smartphone Android yang memiliki kamera dengan resolusi 8 Megapiksel. 


\subsection{Perbandingan Algoritma}

Untuk menentukan panjang badan dan lingkar dada dari suatu gambar diperlukan adanya algoritma untuk melakukan perhitungan tersebut. Sehingga peneliti mencoba mengembangkan enam buah algoritma untuk menghitung panjang badan dan lingkar dada dari citra hasil gambar pada penelitian sebelumnya.
Pada tahap ini akan dijelaskan masing-masing algoritma serta pengukuran kemampuan dari masingmasing algoritma untuk menentukan panjang badan dan lingkar dada dari objek yang diteliti. Algoritma yang diusulkan akan mencoba mencari panjang dan lingkar dada dari objek sapi pada data citra.

Untuk masing-masing usulan algoritma akan dijelaskan dalam bentuk flowchart Gambar 6 .

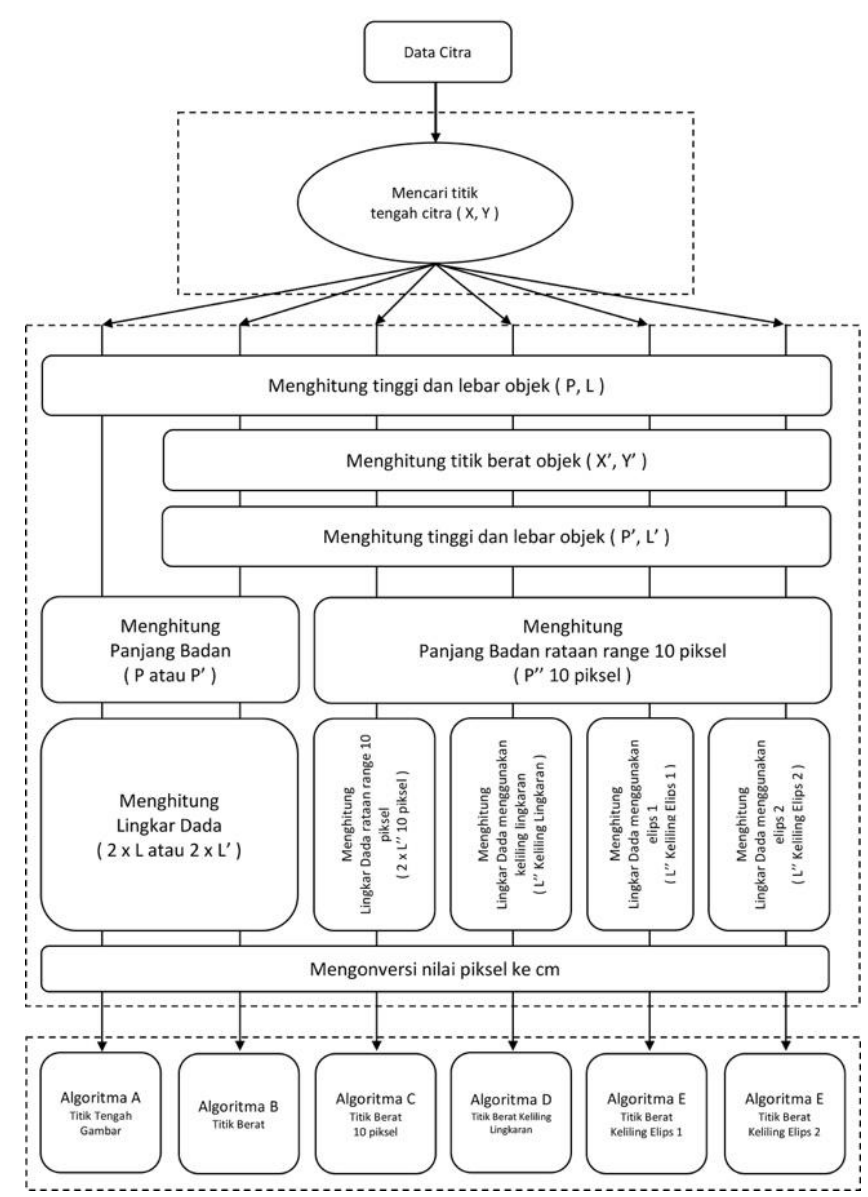

Gambar 6. Flowchart Perbandingan Algoritma

Pada Gambar 6. dijelaskan perbedaan pada masing-masing algoritma yang digunakan, berikut penjelasan langkah-langkah pada masing-masing algoritma.

\section{Algoritma A (Titik Tengah Gambar)}
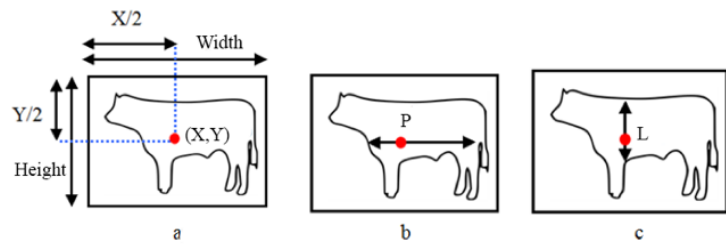

Gambar 7. Alur Kerja Algoritma A (Titik Tengah Gambar)

1. READ Width

2. READ Height

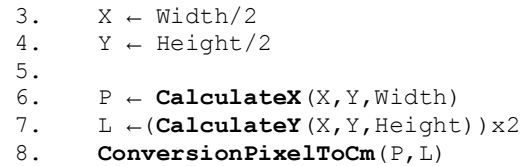

Gambar 7. merupakan simulasi alur kerja dari Algoritma A (Titik Tengah Gambar), yang dijelaskan secara rinci sebagai berikut,

a. Titik tengah citra $(\mathrm{X}, \mathrm{Y})$ dihitung dengan cara membagi 2 panjang piksel citra (Width/2) dan membagi 2 tinggi piksel citra (Height/2).

b. Panjang badan $(\mathrm{P})$ dihitung dengan cara menarik ke arah kiri dan kanan dari titik tengah gambar $(\mathrm{X}, \mathrm{Y})$ sampai menemukan titik garis tepi objek.

c. Lingkar dada (L) dihitung dengan cara menarik garis lurus ke atas dan kebawah dari titik 
tengah gambar $(\mathrm{X}, \mathrm{Y})$ sampai menemukan titik garis tepi objek, setelah menemukan lalu dikalikan 2 untuk mendapatkan nilai lingkar dada.

d. Mengonversi satuan dari piksel ke $\mathrm{cm}$, untuk mendapatkan nilai nyata.

\section{Algoritma B (Titik Berat)}
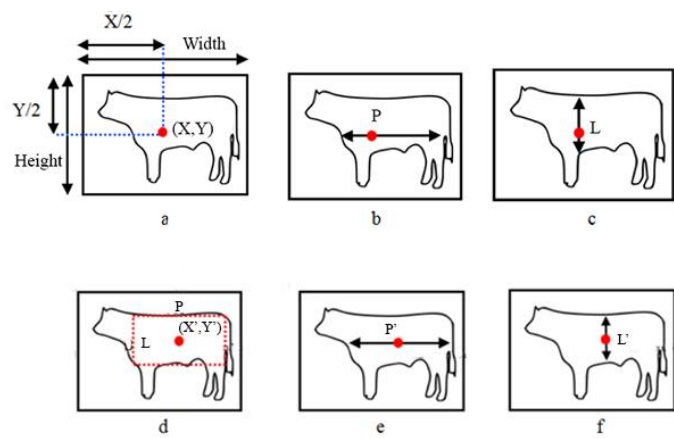

Gambar 8. Alur Kerja Algoritma B (Titik Berat)

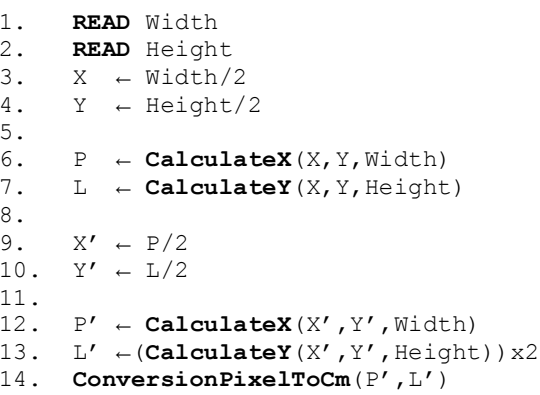

Gambar 8. merupakan simulasi alur kerja dari Algoritma B (Titik Berat), yang dijelaskan secara rinci sebagai berikut,

a. Titik tengah citra $(\mathrm{X}, \mathrm{Y})$ dihitung dengan cara membagi 2 panjang piksel citra (Width/2) dan membagi 2 tinggi piksel citra (Height/2).

b. Panjang objek (P) dihitung dengan cara menarik ke arah kiri dan kanan dari titik tengah gambar $(\mathrm{X}, \mathrm{Y})$ sampai menemukan titik garis tepi objek.

c. Lebar objek (L) dihitung dengan cara menarik garis lurus ke atas dan kebawah dari titik tengah gambar $(\mathrm{X}, \mathrm{Y})$ sampai menemukan titik garis tepi objek.

d. Dengan menggunakan titik berat, objek dapat dimodelkan sebagai persegi panjang. Dengan nilai panjang objek (P) dan lebar objek (L) didapatkan nilai titik berat $\left(\mathrm{X}^{\prime}, \mathrm{Y}^{\prime}\right)$.

e. Panjang badan (P') dihitung dengan cara menarik ke arah kiri dan kanan dari titik berat objek ( $\left.\mathrm{X}^{\prime}, \mathrm{Y}^{\prime}\right)$ sampai menemukan titik garis tepi objek.

f. Lingkar dada (L') dihitung dengan cara menarik garis lurus ke atas dan kebawah dari titik berat objek $\left(X^{\prime}, Y^{\prime}\right)$ sampai menemukan titik garis tepi objek, setelah menemukan lalu dikalikan 2 untuk mendapatkan nilai lingkar dada.

g. Mengonversi satuan dari piksel ke $\mathrm{cm}$, untuk mendapatkan nilai nyata.

\section{Algoritma C (Titik Berat 10 Piksel)}
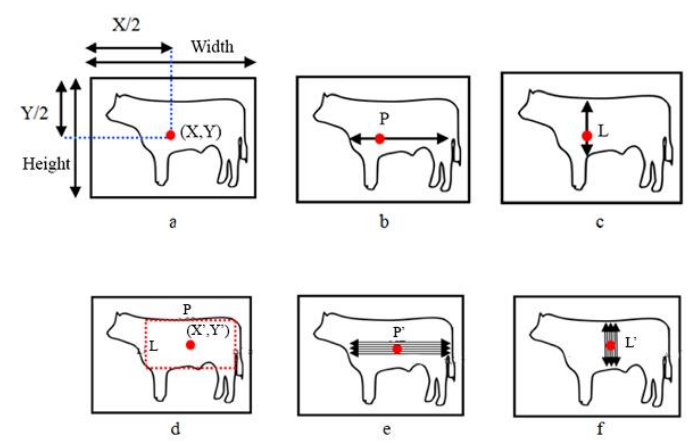

Gambar 9. Alur Kerja Algoritma C (Titik Berat 10 Piksel)

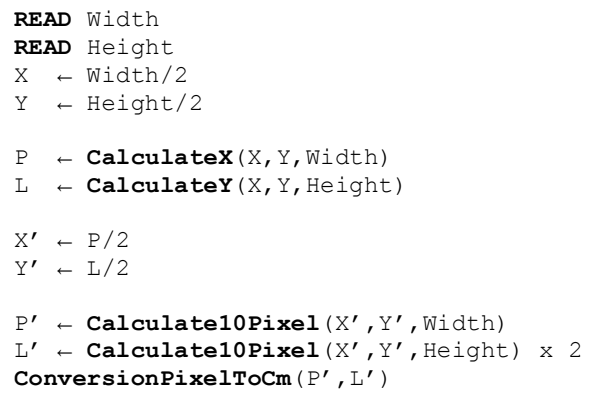

Gambar 9. merupakan simulasi alur kerja dari Algoritma C (Titik Berat 10 Piksel), yang dijelaskan secara rinci sebagai berikut,

a. Titik tengah citra $(\mathrm{X}, \mathrm{Y})$ dihitung dengan cara membagi 2 panjang piksel citra (Width/2) dan membagi 2 tinggi piksel citra (Height/2).

b. Panjang objek (P) dihitung dengan cara menarik ke arah kiri dan kanan dari titik tengah gambar $(\mathrm{X}, \mathrm{Y})$ sampai menemukan titik garis tepi objek.

c. Lebar objek (L) dihitung dengan cara menarik garis lurus ke atas dan kebawah dari titik tengah gambar $(\mathrm{X}, \mathrm{Y})$ sampai menemukan titik garis tepi objek.

d. Dengan menggunakan titik berat, objek dapat dimodelkan sebagai persegi panjang. Dengan nilai panjang $(\mathrm{P})$ dan lebar (L) didapatkan nilai titik berat $\left(\mathrm{X}^{\prime}, \mathrm{Y}^{\prime}\right)$.

e. Panjang badan (P') dihitung dengan cara menarik ke arah kiri dan kanan sebanyak 10 piksel (5piksel keatas dan 5 piksel kebawah) dari titik berat objek $\left(\mathrm{X}^{\prime}, \mathrm{Y}^{\prime}\right)$ sampai menemukan titik garis tepi objek. Kemudian dihitung rataan dari hasil yang didapatkan, didapatkanlah nilai panjang badan (P').

f. Lingkar dada (L') dihitung dengan cara menarik garis lurus ke atas dan kebawah sebanyak 10 piksel (5piksel kekiri dan 5 piksel kekanan) dari titik berat objek $\left(X^{\prime}, Y^{\prime}\right)$ sampai menemukan titik garis tepi objek. Kemudian dihitung rataan dari hasil yang didapatkan, didapatkanlah nilai (L'), setelah itu lalu dikalikan 2 untuk mendapatkan nilai lingkar dada.

g. Mengonversi satuan dari piksel ke $\mathrm{cm}$, untuk mendapatkan nilai nyata. 
Algoritma D (Titik Berat Keliling Lingkaran)
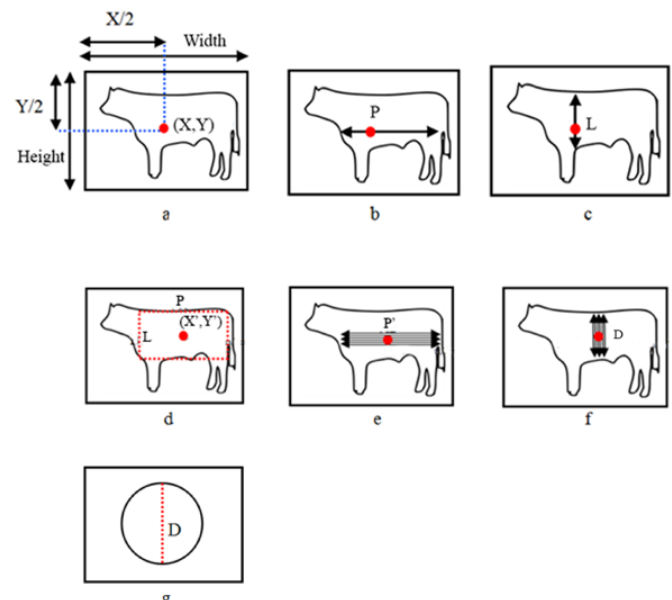

Gambar 10. Alur Kerja Algoritma D (Titik Berat Keliling Lingkaran)

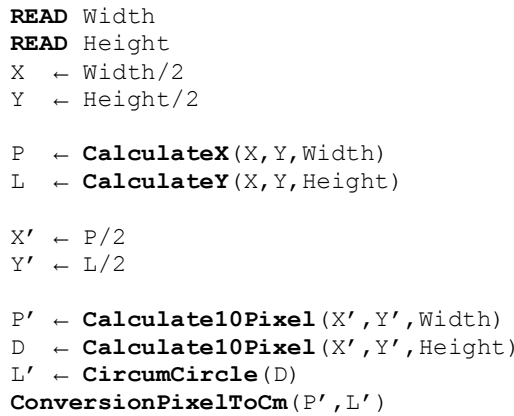

Gambar 10. merupakan simulasi alur kerja dari Algoritma D (Titik Berat Keliling Lingkaran), yang dijelaskan secara rinci sebagai berikut,

a. Titik tengah citra $(\mathrm{X}, \mathrm{Y})$ dihitung dengan cara membagi 2 panjang piksel citra (Width/2) dan membagi 2 tinggi piksel citra (Height/2).

b. Panjang objek (P) dihitung dengan cara menarik ke arah kiri dan kanan dari titik tengah gambar $(\mathrm{X}, \mathrm{Y})$ sampai menemukan titik garis tepi objek.

c. Lebar objek (L) dihitung dengan cara menarik garis lurus ke atas dan kebawah dari titik tengah gambar $(\mathrm{X}, \mathrm{Y})$ sampai menemukan titik garis tepi objek.

d. Dengan menggunakan titik berat, objek dapat dimodelkan sebagai persegi panjang. Dengan nilai panjang $(\mathrm{P})$ dan lebar $(\mathrm{L})$ didapatkan nilai titik berat $\left(\mathrm{X}^{\prime}, \mathrm{Y}^{\prime}\right)$.

e. Panjang badan (P') dihitung dengan cara menarik ke arah kiri dan kanan sebanyak 10 piksel (5piksel keatas dan 5 piksel kebawah) dari titik berat objek $\left(X^{\prime}, Y^{\prime}\right)$ sampai menemukan titik garis tepi objek. Kemudian dihitung rataan dari hasil yang didapatkan, didapatkanlah nilai panjang badan ( $\left.\mathrm{P}^{\prime}\right)$.

f. Diameter (D) dihitung dengan cara menarik garis lurus ke atas dan kebawah sebanyak 10 piksel (5piksel kekiri dan 5 piksel kekanan) dari titik berat objek $\left(X^{\prime}, Y^{\prime}\right)$ sampai menemukan titik garis tepi objek. Kemudian dihitung rataan dari hasil yang didapatkan, didapatkanlah nilai diameter

g. Setelah didapatkan nilai diameter (D), lingkar dada sapi (L') dimodelkan dalam bentuk lingkaran.

h. Lingkar dada (L') dihitung dengan cara mencari keliling dari lingkaran dengan diameter (D) yang sudah ditentukan.

i. Mengonversi satuan dari piksel ke $\mathrm{cm}$, untuk mendapatkan nilai nyata.

\section{Algoritma E (Titik Berat Keliling Elips 1)}
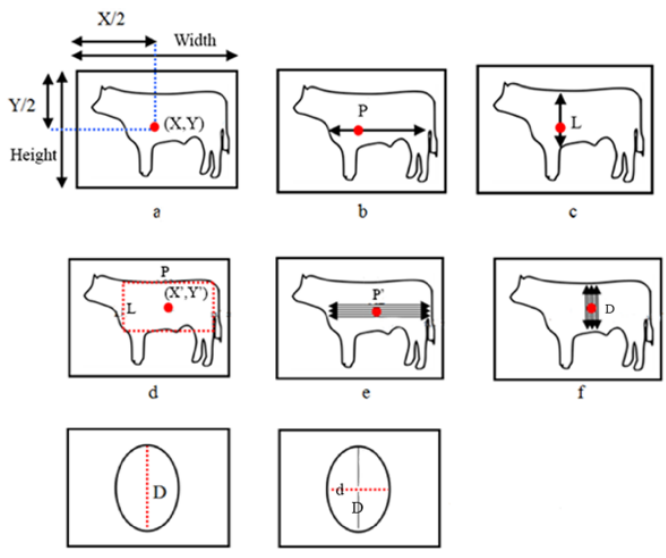

Gambar 11. Alur Kerja Algoritma E (Titik Berat Keliling Elips 1)

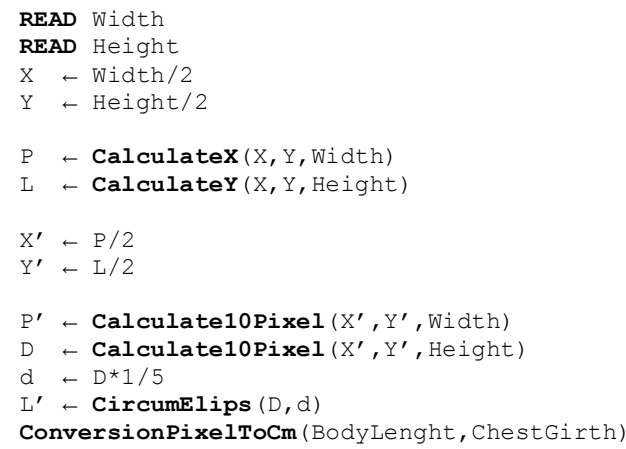

Gambar 11. merupakan simulasi alur kerja dari Algoritma E (Titik Berat Keliling Elips 1), yang dijelaskan secara rinci sebagai berikut,

a. Titik tengah citra $(\mathrm{X}, \mathrm{Y})$ dihitung dengan cara membagi 2 panjang piksel citra (Width/2) dan membagi 2 tinggi piksel citra (Height/2).

b. Panjang objek (P) dihitung dengan cara menarik ke arah kiri dan kanan dari titik tengah gambar $(\mathrm{X}, \mathrm{Y})$ sampai menemukan titik garis tepi objek.

c. Lebar objek (L) dihitung dengan cara menarik garis lurus ke atas dan kebawah dari titik tengah gambar $(\mathrm{X}, \mathrm{Y})$ sampai menemukan titik garis tepi objek.

d. Dengan menggunakan titik berat, objek dapat dimodelkan sebagai persegi panjang. Dengan nilai panjang $(\mathrm{P})$ dan lebar (L) didapatkan nilai titik berat $\left(\mathrm{X}^{\prime}, \mathrm{Y}^{\prime}\right)$. 
e. Panjang badan (P') dihitung dengan cara menarik ke arah kiri dan kanan sebanyak 10 piksel (5piksel keatas dan 5 piksel kebawah) dari titik berat objek (X', Y') sampai menemukan titik garis tepi objek. Kemudian dihitung rataan dari hasil yang didapatkan, didapatkanlah nilai panjang badan (P').

f. Diameter (D) dihitung dengan cara menarik garis lurus ke atas dan kebawah sebanyak 10 piksel (5piksel kekiri dan 5 piksel kekanan) dari titik berat objek ( $\left.\mathrm{X}^{\prime}, \mathrm{Y}^{\prime}\right)$ sampai menemukan titik garis tepi objek. Kemudian dihitung rataan dari hasil yang didapatkan, didapatkanlah nilai diameter

g. Setelah didapatkan nilai diameter (D), lingkar dada sapi (L') dimodelkan dalam bentuk elips dengan perbandingan Diameter Mayor (D) : Diameter Minor (d) $=5: 1$.

h. Lingkar dada (L') dihitung dengan cara mencari keliling dari elips.

i. Mengonversi satuan dari piksel ke $\mathrm{cm}$, untuk mendapatkan nilai nyata.

\section{Algoritma F (Titik Berat Keliling Elips 2)}
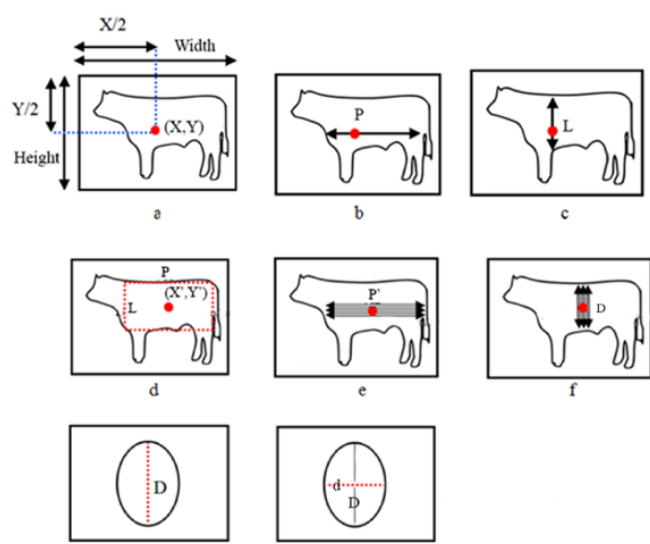

$\mathrm{g}$ h

Gambar 12. Alur Kerja Algoritma F (Titik Berat Keliling Elips 2)

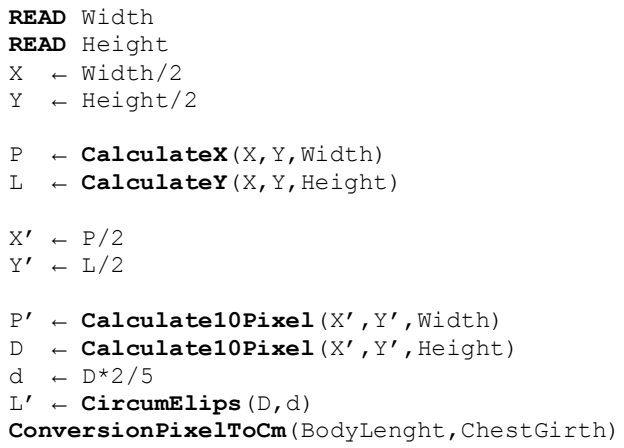

Gambar 12. merupakan simulasi alur kerja dari Algoritma F (Titik Berat Keliling Elips 2), yang dijelaskan secara rinci sebagai berikut,

a. Titik tengah citra $(\mathrm{X}, \mathrm{Y})$ dihitung dengan cara membagi 2 panjang piksel citra (Width/2) dan membagi 2 tinggi piksel citra (Height/2).

b. Panjang objek (P) dihitung dengan cara menarik ke arah kiri dan kanan dari titik tengah gambar $(\mathrm{X}, \mathrm{Y})$ sampai menemukan titik garis tepi objek.

c. Lebar objek (L) dihitung dengan cara menarik garis lurus ke atas dan kebawah dari titik tengah gambar $(\mathrm{X}, \mathrm{Y})$ sampai menemukan titik garis tepi objek.

d. Dengan menggunakan titik berat, objek dapat dimodelkan sebagai persegi panjang. Dengan nilai panjang $(\mathrm{P})$ dan lebar (L) didapatkan nilai titik berat $\left(\mathrm{X}^{\prime}, \mathrm{Y}^{\prime}\right)$.

e. Menghitung panjang badan (P') dengan cara menarik ke arah kiri dan kanan sebanyak 10 piksel (5piksel keatas dan 5 piksel kebawah) dari titik berat objek $\left(X^{\prime}, Y^{\prime}\right)$ sampai menemukan titik garis tepi objek. Kemudian dihitung rataan dari hasil yang didapatkan, didapatkanlah nilai panjang badan (P').

f. Diameter (D) dihitung dengan cara menarik garis lurus ke atas dan kebawah sebanyak 10 piksel (5piksel kekiri dan 5 piksel kekanan) dari titik berat objek $\left(X^{\prime}, Y^{\prime}\right)$ sampai menemukan titik garis tepi objek. Kemudian dihitung rataan dari hasil yang didapatkan, didapatkanlah nilai diameter

g. Setelah mendapatkan nilai diameter (D), lingkar dada sapi (L') dimodelkan dalam bentuk elips dengan perbandingan Diameter Mayor (D) : Diameter Minor $(\mathrm{d})=5: 2$.

h. Lingkar dada (L') dihitung dengan cara mencari keliling dari elips.

i. Mengonversi satuan dari piksel $\mathrm{ke} \mathrm{cm}$, untuk mendapatkan nilai nyata.

\subsection{Evaluasi}

Pada tahap ini 10 data citra (Kode J sampai S) akan dievaluasi dan dihitung serta dibandingkan dengan nilai hasil oleh algoritma yang diusulkan. Alasannya kenapa tidak menggunakan 19 data awal. Dikarenakan proses akuisisi citra pada 9 data awal masih menggunakan batasan jarak antara kamera dengan objek yaitu $150 \mathrm{~cm}$ sampai $200 \mathrm{~cm}$. Setelah melakukan analisis ternyata variabel jarak sangat berpengaruh pada proses konversi satuan. Sehingga data dari proses akuisisi yang digunakan hanya 10 data citra (Kode J sampai S) yang diambil dari jarak pengambilan sebesar $150 \mathrm{~cm}$.

Nilai yang dihasilkan oleh rumus Modifikasi/Lambourne kemudian dibandingkan dengan nilai dari hasil algoritma usulan.

Hasil lingkar dada dan panjang badan dari usulan algoritma dibandingkan dengan nilai dari hasil rumus Modifikasi/Lambourne mendapatkan nilai MAE (Mean Absolute Error) untuk setiap algoritma yang diusulkan. Hasil perhitungan ditunjukkan oleh Gambar 13. semakin kecil nilai yang dihasilkan maka semakin bagus algoritma.

Nilai perbandingan MAE (Mean Absolute Error) pada bobot badan untuk setiap algoritma yang diusulkan dibandingkan dengan nilai hasil bobot badan pada rumus modifikasi/Lambourne. Hasil perhitungan ditunjukkan oleh Gambar 14. semakin 
kecil nilai yang dihasilkan maka semakin bagus algoritma.

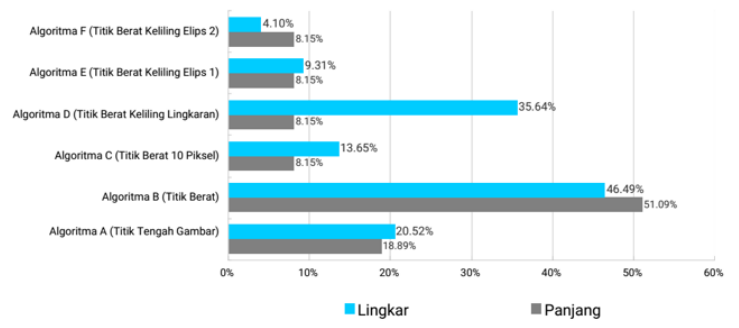

Gambar 13. Diagram perbandingan MAE (Mean Absolute Error) lingkar dada dan panjang badan

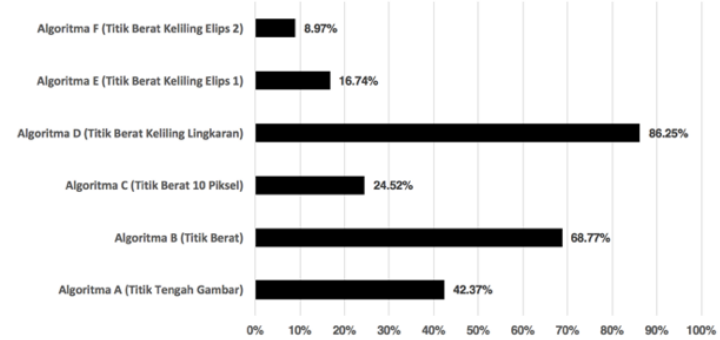

Gambar 14. Diagram perbandingan MAE (Mean Absolute Error) Bobot badan

\section{KESIMPULAN}

Aplikasi pengolahan citra digital yang dibagun dapat mengetahui bobot sapi dengan menggunakan variabel panjang badan dan lingkar dada.

Hasil penentuan bobot sapi menggunakan rumus Schoorl dan rumus Modifikasi/Lambourne memiliki nilai deviasi bobot badan sebesar $16,87 \%$ untuk rumus Schoorl dan nilai penyimpangan bobot badan sebesar 10,58 \% untuk rumus Modifikasi/Lambourne.

Nilai varian yang besar dari rumus Schoorl dan rumus Modifikasi/Lambourne menunjukkan bahwa masih diperlukan adanya penelitian selanjutnya yang dapat membuat rumus baru untuk menentukan berat badan sapi secara lebih tepat dengan nilai varian yang lebih kecil.

Dari hasil analisis dan evaluasi yang telah dilakukan menunjukan bahwa Algoritma F (Titik Berat Keliling Elips 2) merupakan algoritma yang terbaik dalam menghitung panjang badan, lingkar dada, dan bobot badan.

Hasil analisis perbandingan algoritma untuk menentukan panjang badan dan lingkar dada hasil perhitungan citra tidak berbeda secara signifikan yaitu dengan faktor ketelitian secara statistis dengan MAE (Mean Absolute Error) sebesar 8,15\% untuk panjang badan dan 4,10\% untuk lingkar dada. Hasil analisis penentuan berat badan/bobot sapi dari hasil perhitungan citra memiliki faktor ketelitian secara statistis dengan MAE (Mean Absolute Error) sebesar $8,97 \%$ terhadap rumus Modifikasi/Lambourne.

\section{DAFTAR PUSTAKA}

ABIDIN, Z., 2002. Penggemukan Sapi Potong. Jakarta: AgroMedia Pustaka.

CHOLISSODIN, I., SOEBROTO, A.A., Hidayat, N., 2015. Integrasi Metode fuzzy Additive SVM(FASVM) Menggunakan Model Warna YUV-CMY-HSV untuk Klasifikasi Bibit Unggul Sapi Bali Melalui Citra Digital, 2(2), p.110-115. Malang: Jurnal Teknologi Informasi dan Ilmu Komputer (JTIIK).

ENSMINGER, M.E., OLENTINE, C.G., 1980. Feeds and Nutrition Complete. West Sierra Avenue Clovis California: The Ensminger Publishing Company.

KEMENTAN - BPS, 2011. Rilis Hasil Akhir PSPK2011. Kementerian Pertanian - Badan Pusat Statistik.

LASFETO, D. B., SUSANTO, A., \& AGUS, A., 2012. Aplikasi Pengolahan Citra untuk Estimasi Bobot Badan Ternak Sapi. Buletin Peternakan, 32(3), p.167-176. Yogyakarta: Buletin Peternakan (Bulletin of Animal Science). doi:10.21059/buletinpeternak.v32i3.1254

MUNIR, R., 2004. Pengolahan Citra Digital Dengan Menggunakan Pendekatan Algoritmik. Bandung: Informatika.

MUSTAFID, A., 'UYUN, S., 2017. Segmentasi Citra Sapi Berbasis Deteksi Tepi Menggunakan Algoritma Canny Edge Detection. Jurnal Buana Informatika, 8(1), , p.27-35. Yogyakarta: Fakultas Teknologi Industri Universitas Atma Jaya Yogyakarta. doi:10.24002/jbi.v8i1.1074

PAPUTUNGAN, U., HAKIM, L., CIPTADI, G., \& LAPIAN, H. F. N., 2013. The Estimation Accuracy of Live Weight from Metric Body Measurements in Ongole Grade Cows. Journal of the Indonesian Tropical Animal Agriculture, 38(3), doi:10.14710/jitaa.38.3.149-155

PRADANA, Z., HIDAYAT, B. AND DARANA, S., 2016. Beef cattle weight determine by using digital image processing. 2016 International Conference on Control, Electronics, Renewable Energy and Communications (ICCEREC). doi:10.1109/ICCEREC.2016.7814955

PURNOMO, M.H., MUNTASA, A., 2010. Konsep Pengolahan Citra Digital dan Ekstraksi Fitur. Yogyakarta: Graha Ilmu.

RAJPUT, R.K., 1988. A Textbook of Applied Mechanics. India: Laxmi Publications. 
Halaman ini sengaja dikosongkan 